\title{
The Design of Female Presentation in TV Beer Commercial
}

\author{
Tsung-Nan Shen \\ Department of Communications Management, Shih Hsin University, Taiwan \\ Email: jason@mail.shu.edu.tw
}

How to cite this paper: Shen, T.-N. (2022). The Design of Female Presentation in TV Beer Commercial. Sociology Mind, 12, 20-27. https://doi.org/10.4236/sm.2022.121002

Received: November 24, 2021

Accepted: January 4, 2022

Published: January 7, 2022

Copyright (C) 2022 by author(s) and Scientific Research Publishing Inc. This work is licensed under the Creative Commons Attribution International License (CC BY 4.0).

http://creativecommons.org/licenses/by/4.0/

\begin{abstract}
TV commercial is one of the most important promotion channels, it can not only stimulate the sales number of products but also insert the cultural meaning into consumer's mind. However, inappropriate commercial design may lead to audience's misconception of the product, and it could be harmful to the corporate's image. Based on the main consumptions of the target audience of beer, mostly male consumers, female are always chosen to be the main character of beer commercial, repetitively appeared as objectified or discriminated characters in the commercial. Results show that the shot distance and the bending and lifting angles used are correlated with the degree whether female are treated equally. If camera techniques were used properly, avoiding using the objectifying female semiotics, then the improper situation of sexual discrimination would be decreased.
\end{abstract}

\section{Keywords}

Beer Commercial, Semiotics, Camera Techniques, Sexual Discrimination

\section{Introduction}

In modern society, TV commercial is one of the most persuasive media, which not only reflects but also has the influence to shape culture. Due to the mass production of merchandise, modern advertisements and marketing skills have grown rapidly, and advertisements have become an important part of the economic institutions of capitalism. All kinds of advertising, marketing, packaging, and design keep out with the old, in with the new to convince the consumers continuing consume lots of new products. According to the statistics, advertisements account for one sixth of time of TV programs. In other words, when audience watches these commercials for a long time, it is possible that they would be unconsciously influenced by the ideology conveyed in the advertisement's 
messages.

For a long time, media has played the role of creating and breaking the stereotypes; however, media has also strengthened the existing stereotypes for specific consumer groups. In recent years, there has been an abundance of advertisements that objectify women, using women as attraction and sex object, distorting their contributions in the workplace and emphasizing their subordinate role to mislead children's perception of men and women. Sexual discrimination also includes male, homosexual, bisexual, and transgender discrimination. However, most beer advertisements usually discriminate against women. This study aims to balance the perception of role of women in society by compiling a comprehensive design of the female gender that selects an appropriate design which would not result in discrimination but would assist in the product consumption.

\section{Literature Review}

In modern society, advertising has permeated into our daily lives, it surrounds us in the form of mass media, streets, and everyone's homes. As Leiss, Kline and Jhally (1990) stated, the significance of advertising in the society lies in that it can influence consumers' purchase decisions. The main purpose of advertising design is to attract the audiences' attention, allow them to understand the products, and change their attitudes so that they will take action (Pollay, 1986). Even though not all advertisements achieve these purposes, every single advertiser still invested huge amounts of funds for advertising marketing.

Under the traditional gender structure, men are the breadwinners while women are housewives, and different personal characteristics have been given to both genders. In the long run, both gender's behavioral habits are shaped: tough is the adjectives for men and frail is used to described women. At the same time, the stereotype of housework is deeply rooted in everyone's mind. After WWII, feminism has awaken to reexamine the traditional gender roles, and started the pursuit of economic independence, equal pay for equal work, and the right of participating citizen, public, and politic affairs, etc. However, while prospered from time to time, mass media, especially advertisements, did not reflect the current situation loyally. Therefore, it leads to different perception of gender relationship, and then creates new problems of perception of gender roles.

Gender roles of advertisements have been valued in different fields. Whipple \& Courtney (1985) has pointed out that the mislead message of female roles could influence the mass audience's perception of female, such as stupid, discrimination toward feminism, and would degrade female's self-dignity.

Atkin's (1993) research shows that media has stressed the positive images of beer drinking in advertisements, movies, TV programs, even the warnings of public service announcements. Through analyzing several beer ads, Horton (1992) found that fast tempo, catchy tunes, smile faces, and happy, hustle and bus- 
tleatmosphere are frequent used elements to attract young audience. However, these ads also conveyed distorted messages as follows:

Beer ads attract male youngsters through some specific cultural rites. For example, drinking beer could make a young boy turned into a real man and share his friendship with others. One of the repetition themes of beer ads is that male groups always hang out together. In these activities, female is excluded or subordinate. Some beer ads link beer with fast-pace risky activities, such as horse-riding, speedboat driving, street racing in the black night with the rain. Female characters are degraded in beer ads: most of the female character functions nothing but a pretty face or serve as a waitress. Also, female characters are frequently objectified, exaggerating their sexuality to lure the audience. Bars are positively depicted in beer ads. What ads do not tell are the scenes of flinging abuses, quarrel, and vomit due to overdrink.

In the field of TV commercial, semiotics research plays an important and significant role. Among all, Peirce and Saussure were viewed as the progenitors of semiotics. Peirce developed a system to examine the relationships of a sign and the object it signified, which contains three different types of signs: the icon, the index and the symbol (Fiske, 1990). Saussure (1916)'s semiotics discussed the system of linguistic signs in applying numerous advertising research. Among linguistic signs, Saussure defined the relationship of the signifier and the signified. The so-called signifier could be a video in the physical world, an object or a word, and through different experiences of the audience, it could generate different perception toward the same signifier it signified. When analyzing, Saussure used two combination systems, one is paradigmatic relations, and the other is syntagmatic relations. Paradigmatic relations include a set of vertical category elements, and these elements could be similar or contrary in meaning, the users choose one of them to combine with other elements. On the other hand, syntagmaticrelations arrange words in the horizontal level, considering the general syntax meaning of the chosen signs. Therefore, signs are polysemous, and the relationships between signs and meaning are not fixed: a meaning could have numerous representative signs, and a sign could symbolize different meaning.

The camera techniques in TV commercial, also represents its unique meanings. Berger (2012) believed that close shot could stand out the details of the screen and generate close relationship between the viewer and the situation shot. For example, high-angle shot symbolizes tiny and weak of the actor, and the low-angle shot signifies power and dignified traits of the viewer, as Table 1 shows.

\section{Method}

The study uses text analysis to examine how the elements used in beer ads function. According to the intention toward female, the study classified three different types: first level viewed women as sexual objects, the second level judge women as stupid, i.e., women's driving skill is worse than men, and the last one 
Table 1. TV grammar of camera meaning.

\begin{tabular}{ccc}
\hline Signifier (shot) & Definition & Signified (meaning) \\
\hline $\begin{array}{c}\text { close-up } \\
\text { medium shot }\end{array}$ & face only & $\begin{array}{c}\text { intimacy } \\
\text { most of body }\end{array}$ \\
personal relationship \\
cong shot & setting and characters & public distance \\
full shot & full body of person & social relationship \\
pan down & camera looks down & power, authority \\
pan up & camera looks up & smallness, weakness \\
zoom in & camera moves in & observation, focus \\
fade in & images appear on blank screen & beginning \\
fade out & images screen goes blank & ending \\
cut & switch from one image to another & simultaneity, excitement \\
wipe & image wiped off screen & imposed conclusion \\
\hline
\end{tabular}

treat female equally, let them confidently express themselves. With this principle, the study finds three beer ads to examine how gender functions as a sign in the system of advertisement representation. The following are three contexts of sample advertisements:

\section{A: "Episode: sharing with friends"}

The camera remains focused on the picture of the women lying on her stomach and the beer bottle on her back. First someone behind her takes a sip and puts the bottle back on her back. Next, someone in front of her also takes a sip and carefully places it back (The subtitle appears: "share one with a friend"). Next, someone below the woman takes the bottle and again places it back, then the subtitle appears: "or two (friends)". The woman simply stays in position and wiggles from beginning to end.

B: "Episode: parking"

The scene is set around a century ago, a young woman struggles to park a carriage to the side of the road, while two men drinking beer are onlookers who cannot stop laughing. Next, the advertisement scenario jumps to the present, the same young woman is still unable to park the car, and finally parks it crooked roadside. At this moment, the narrative along with sound effects start: "fortunately, some things never change".

C: "Episode: self-entertainment"

It begins from a man using a camera to secretly take pictures of a beautiful woman in the next building. The beautiful woman seems to know someone is taking photos of her, as she continues to pose sexily through the glass window. In the process she attracts the attention of a crowd and receives cheers of appraisal as she moves.

\section{Results}

Finding a view is closely related to the level of woman being objectified. In film 
A, there is extensive use of a close-up picture, including the scene that zooms from the close up of the bottle to the back of the naked woman, as shown in Figure 1.

Next, a close up is also utilized when three different individuals grab the same beer from different directions, as shown in Figure 2.

Finally, the subtitle appears: share one with a friend. Or two, as shown in Figure 3.

Film B includes a mixture of close-ups, middle shots, and high angle shots. It starts from a middle shot bringing in the picture of a woman parking the carriage, as shown in Figure 4.

The picture zooms in to focus on the bad parking techniques of the woman, and the condescending look of the men watching her, as shown in Figure 5.

The picture uses high-angle shot and middle shot to emphasize on how the woman parks the car crookedly, as shown in Figure 6.
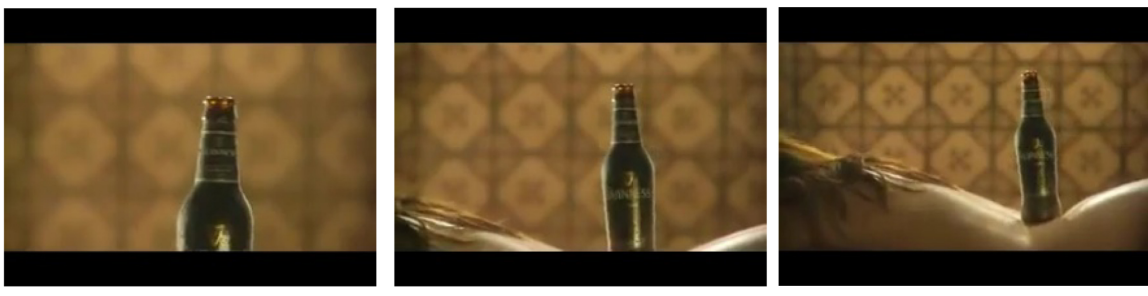

Figure 1. Part 1 of film A.
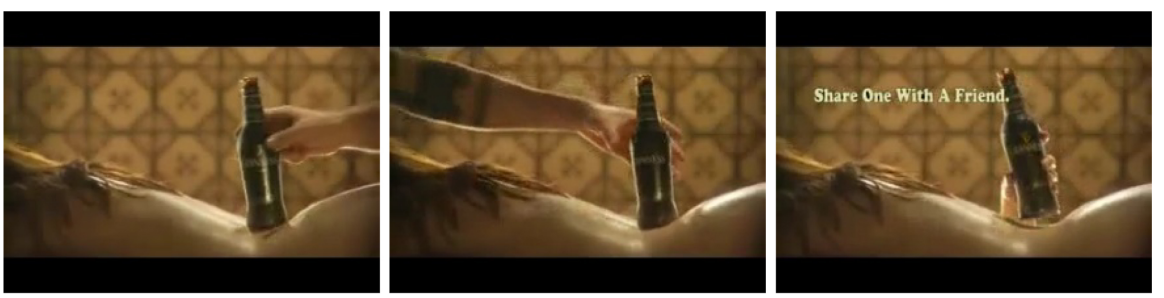

Figure 2. Part 2 of film A.

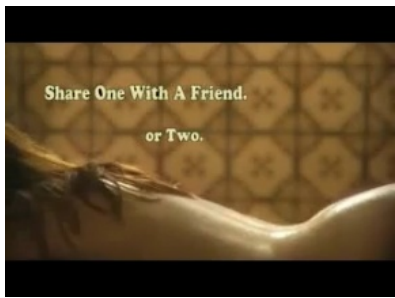

Figure 3. Part 3 of film A.
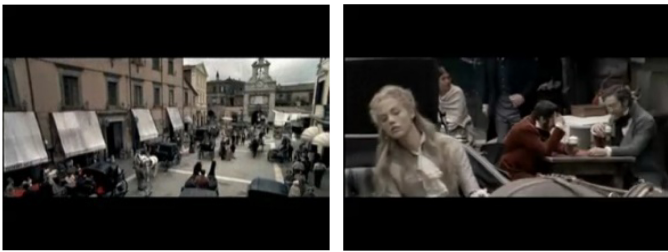

Figure 4. Part 1 of film B. 
Finally, the subtitles appear: Some things never change, as shown in Figure 7.

Film $\mathrm{C}$ uses long shot and low angle shot. It starts from the female protagonist taking out beer from the fridge and posing sexily, as shown in Figure 8.

Next, the crowd views the woman from a low angle, and finally cheering in praise of the woman, as shown in Figure 9.

The picture of the female protagonist is presented by a long shot showing the crowd looking up, and the woman looking down, finally ending with a long shot, as shown in Figure 10.
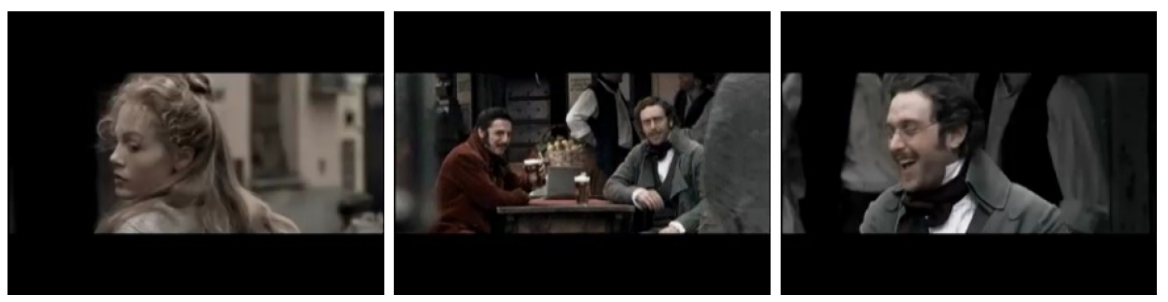

Figure 5. Part 2 of film B.
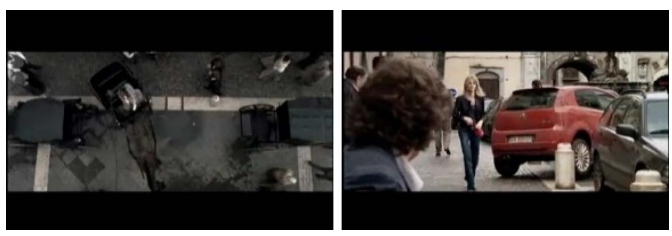

Figure 6. Part 3 of film B.

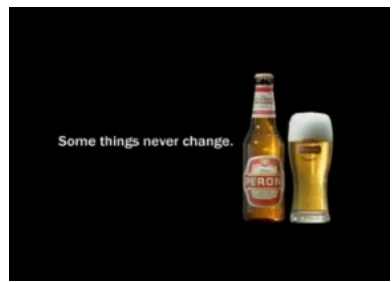

Figure 7. Part 4 of film B.
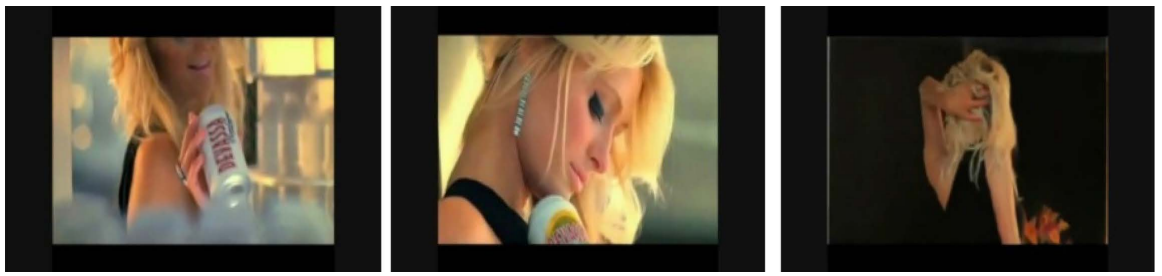

Figure 8. Part 1 of film C.
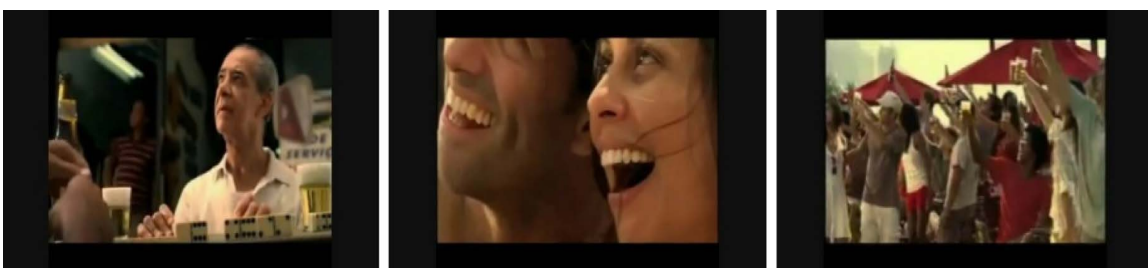

Figure 9. Part 2 of film C. 

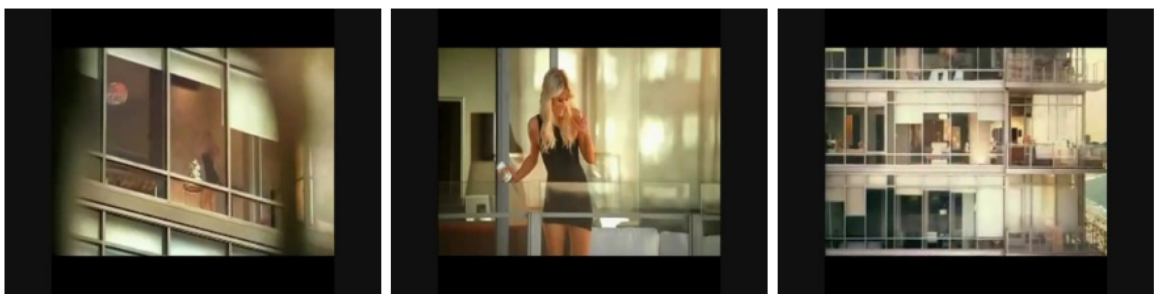

Figure 10. Part 3 of film C.

Table 2. Symbolic analysis of adcontent.

\begin{tabular}{|c|c|c|c|c|c|c|c|}
\hline & film & who & what & when & denotation & connotation & $\begin{array}{l}\text { Sexual } \\
\text { myths }\end{array}$ \\
\hline & A & $\begin{array}{l}\text { Back of a } \\
\text { nude } \\
\text { woman }\end{array}$ & $\begin{array}{l}\text { Places a } \\
\text { bottle on } \\
\text { her back } \\
\text { and } \\
\text { wiggles } \\
\text { front and } \\
\text { back }\end{array}$ & $\begin{array}{l}\text { Short } \\
\text { moment }\end{array}$ & $\begin{array}{l}\text { Three men } \\
\text { have a sexual } \\
\text { relationship } \\
\text { with a woman } \\
\text { at the } \\
\text { same time }\end{array}$ & $\begin{array}{l}\text { A beer brand } \\
\text { which could } \\
\text { be shared } \\
\text { with friends }\end{array}$ & $\begin{array}{l}\text { Women } \\
\text { could be } \\
\text { shared }\end{array}$ \\
\hline 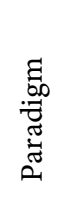 & B & $\begin{array}{l}\text { Young } \\
\text { woman }\end{array}$ & $\begin{array}{l}\text { Cannot } \\
\text { park a } \\
\text { car }\end{array}$ & $\begin{array}{l}\text { From } \\
\text { carriage } \\
\text { generation } \\
\text { to car } \\
\text { generation }\end{array}$ & $\begin{array}{l}\text { Some things } \\
\text { never change }\end{array}$ & $\begin{array}{l}\text { Drinking } \\
\text { this brand } \\
\text { of beer } \\
\text { never } \\
\text { changes }\end{array}$ & $\begin{array}{l}\text { Women } \\
\text { cannot } \\
\text { park cars }\end{array}$ \\
\hline & $\mathrm{C}$ & $\begin{array}{l}\text { Hot } \\
\text { woman }\end{array}$ & $\begin{array}{l}\text { The } \\
\text { process of } \\
\text { drinking } \\
\text { beer along } \\
\text { with the } \\
\text { music }\end{array}$ & $\begin{array}{l}\text { A short } \\
\text { time }\end{array}$ & $\begin{array}{l}\text { The sexy poses } \\
\text { win over the } \\
\text { approval and } \\
\text { cheers of the } \\
\text { crowd }\end{array}$ & $\begin{array}{l}\text { A sexy beer } \\
\text { brand }\end{array}$ & $\begin{array}{l}\text { A woman } \\
\text { with a hot } \\
\text { body who } \\
\text { acts sexy } \\
\text { will be } \\
\text { popular. }\end{array}$ \\
\hline & \multicolumn{7}{|c|}{ Syntagm } \\
\hline
\end{tabular}

The implications of the symbolic analysis are organized in Table 2.

\section{Conclusion}

Despite the rise of online media, television advertising is still a significant broadcasting channel for businesses. A beer advertisement includes no less than the combination of a pleasant scenario and attractive men and women. Since the target consumers of alcohol are men, females tend to appear in commercial as protagonists, and they are usually objectified. In today's world of high consumer consciousness and rapid flow of information, a small inadvertent error, such as sexual discrimination against woman, may bring a major crisis for the company. Therefore, the gender presentation in advertising should be paid special attention.

In the symbolic sense, there are different presentation methods of the female symbol. Being naked and having poor abilities are common stereotypes. The 
naked symbol will usually allow people to associate with sex, while poor abilities are typical gender discrimination. A slim figure is a symbol of women, if this symbol utilizes space for a single female character, then it is a more neutral and safer gender presentation designs.

The results of this study show that the camera techniques in television advertisements are related to gender presentation design. Close-range or close-up shots will usually allow the audience to feel intimacy, while a high-angle shot is condescending, if it is paired with symbolic design that objectifies women, it will result in an advertisement that discriminates against women and provoke antipathy from women. On the other hand, if a middle or long shot is utilized in addition to a low-angle shot at the female antagonist, it can reduce the possibility of creating an inappropriate advertisement.

\section{Conflicts of Interest}

The author declares no conflicts of interest regarding the publication of this paper.

\section{References}

Atkin, C. K. (1993). Effects of Media Alcohol Messages on Adolescent Audiences. Adolescent Medicine, 4, 527-542.

Berger, A. A. (2012). Media Analysis Techniques (4th ed.). Sage.

Fiske, J. (1990). Introduction to Communication Studies (2nd ed.). Routledge.

Horton, L. (1992). Developing Effective Drug Education Programs. Bloomington: Phi Delta Kappa Educational Foundation.

Leiss, W., Kline, S., \& Jhally, S. (1990). Communication in Advertising: Persons, Products and Images of Well-Being Scarborough. Nelson Canada.

Pollay, R. W. (1986). The Distorted Mirror: Reflections on the Unintended Consequences of Advertising. Journal of Marketing, 50, 18-36. https://doi.org/10.1177/002224298605000202

Saussure, F. (1916). Cours de Linguistique Général. In C. Bally, \& A. Sechehaye (Eds.), Lausanne-Paris: Payot.

Whipple, T., \& Courtney, A. (1985). Female Role Portrayals in Advertising and Communications Effectiveness: A Review. Journal of Advertising, 14, 4-17.

https://doi.org/10.1080/00913367.1985.10672951 